\title{
CONCEPTS OF SELF-REALIZATION, FREEDOM, FREE WILL AND DETERMINISM IN AMERICAN PHILOSOPHY
}

\section{Özlem ÖZEN ${ }^{1}$}

Öz: Amerikan felsefesi konusunu bir çok farklı alandan almaktadır. Bunlardan birisi de bireyin kainattaki durumuyla birlikte, birey Allah ilişkisini inceleyen dini görüşür. Buna göre, insan tabiatının kurtuluşa ermesi için Allah'a ihtiyaç duyduğu düşüncesi bireyin ahlaki hürriyetiyle ve dolayısıyla da bireyin ait olduğu topluma katkılarıyla çok yakından ilintilidir. Allah'ın kendi varlığını dünyada tecelli ettirmesiyle Onun vüce varlığını daha iyi algılamak için, yaratılmış varlıklar içinde en zeki ve en değerli vasıflara sahip biri olan, bireyin belli bir süreçten geçmeye ihtiyacı vardır. $\mathrm{Bu}$ da onun kendini gerçekleştirmesi ve başarıya ulaşmasına yol açmaktadır. $\mathrm{Bu}$ makalede amaçlanan bireyin toplumundaki konumunu Allah'1 idrak edişiyle bağlantılı bir biçimde göstermektir. Burada incelemek üzere seçilen üç tanınmış Amerikalı felsefeci,on dokuzuncu yüzyıl Amerikan düşüncesine göre önemli bir yere sahiptir. J.Royce, J.Edwards ve R.W.Emerson, aralarında bazı düşünce farklılıkları olmasına rağmen, birey ve Allah ilişkisi bakımından tartı̧ılması gerekli olan düşünce yollarını geliştirmişlerdir. Bu düşünce biçimini irdelemek için, kendini-gerçekleştirme, hürriyet ve hür irade, ve determinism (gerekircilik) kavramlarının irdelenmesi gereklidir;.sonuç olarak bu da Allah'ın bireyin toplumdaki tecrübeleri yoluyla tecelli ettiği anlayışına ışık tutacaktır. Bunun yanısıra, bu kavramları karşılaştırmalı olarak irdelemek, bu üç filozofun düşünce biçimleri arasındaki fark1 ortaya koymak amacıyla önem kazanır. Dolayısıyla, birtakım tecrübeler edinirken birey, iyinin ve kötünün farkına varacak, ki bu da içinde yaşadığı toplumun gelişimine yol açacaktır.

Anahtar Sözcükler: Kendini-Gerçekleştirme, Hür İrade, Determinizm (Gerekircilik), J. Royce, J. Edwards, R.W. Emerson.

\section{Introduction}

In their most critical moments, American philosophers argue that philosophy must reassert itself as an active, constructive, and ethical force in human life. Doing this means shaking and breaking many traditional philosophical distinctions including those between: mind and body, fact and value, appearance

\footnotetext{
1 Yrd. Doç. Dr., Osmangazi Üniversitesi, Fen Edebiyat Fakültesi, Karşılaştırmalı Edebiyat Bölümü. ozlemerganozen@gmail.com
} 
and reality, self and society, probability and certainty, and language and world. The three prominent philosophers chosen to be discussed have an important place in the 19th century American thought because of their philosophical themes developed and sustained, such as R.W. Emerson's Transcendentalism and J. Royce's Idealism, J.Edwards' Occasionalism. I wish to set forth the teachings of these philosophers which seem to me interesting to delve into the relationship between man and God. To grasp the existence of God who expresses Himself in the world, the individual, as the most intelligent and precious thing in the creation, needs to go through a process that leads him achieve self-realization and accomplishment. In order to point out this notion, I aim at examining the concepts of the self-realization, freedom and free will, and determinism through a comparative approach in the ways of thinking of three American thinkers, J. Royce, J. Edwards and R.W. Emerson in order to reach the idea that God manifests Himself through individual's deeds and his relationship with the divine.

Before starting to discuss these concepts in the philosophies of these thinkers, I would like to make a distinction among their ways of thinking. Firstly, J. Edwards, as a Calvinist theologian, maintains that uniformity of nature is an arbitrary constitution of the divine will. Emerson, being a transcendentalist, gives himself to the task of developing a new idealist philosophy which was capable of renewing the world in such a way that materialism and traditional religion were not able to renew. And J. Royce, an "absolute idealist," describes God as "Absolute thought" in The Religious Aspect of Philosophy. While for Emerson, who focuses on self-reliance and the individualism in his philosophy. Nature is the remote projection of God in the unconscious.

\section{Self-realization}

In dealing with the problem of Being related to the idea of "Absolute thought", Royce uses the term "self-realization" in the sense that goodness is found in a form of self-realization. Taking the concept of self-realization as my starting point, I agree with Royce whose conception of the problem of Being is closely related to the idealist tradition-- the tradition that signifies the fact that the world is the self-realization of the Absolute thought. In other words, he sees the world as an embodiment of an absolute system of ideas. Royce also interprets the term "individual" through the idealist tradition: an individual being is "a Life of Experience fulfilling Ideas, in an absolutely final form..." (McDermott, 1985, p. 171).

The critic Copleston asks the question: "How can we explain the idealist tradition of Being by the internal meaning of ideas that are considered as the partial fulfillment of a purpose?" (1967, p. 87). According to Royce, the answer to this question lies in the view that an absolute system of ideas itself is the partial fulfillment of the divine will. In this sense, Royce sheds light to the concept of God-man relationship. God, expressing Himself in the world, is the 
ultimate Individual. Therefore, each finite self becomes an expression of the divine purpose.

Royce asserts that each finite self has its own way of expressing and responding itself to its social environment. Furthermore, each finite self seeks the Absolute; in other words, every finite self seeks to unite its will with the divine will. At this point another question arises: can a totally a free finite self decide or choose to obey or rebel the divine will? Royce claims that though a man who has clear knowledge of what he ought to do will act in accordance with this knowledge, he can voluntarily concentrate his attention elsewhere, so that he no longer has clear knowledge of what he ought to do.

The individual can't experience self-realization or true selfhood without a proper life-goal which would be achieved through communication with others, and through self-interpretation in a social environment. This philosophy explains Royce's idea: our individuality in our act is our freedom. Thus, true interpretation of one's self leads to self-realization. This is an important point regarding the relationship between the individual and the society as well as the one between the individual and God.

\section{Freedom and Free will}

From this angle, I need to elaborate on the idea that each self serves to the contribution that fulfills the general purpose of God. If I am a unique self that can act freely, that doesn't necessarily mean that [When I will, God wills in me] my act is a part of God's will. Since the experience belongs to me, it's me who wills God only wills through my will. Thus, the individual as a form of life or experience contributes to the realization of God's divine plans. Since life goes on, the experience of the individual gets richer and richer. This results in the fulfillment of divine plans. In another sense, Royce's philosophy can be seen as one nearing to the tradition of personal idealism according to which the perfection of personality comes first; and the ultimate existence of Being comes later.

Royce also aims at expressing his philosophy of community in terms of the concept of experience. This concept is related to the concept of community including every individual as the unit of experience. So, every individual is free to join his life-task in realizing his experience with free will. Even the concept of choice in Royce's philosophy of Absolute Thought is based on the will and moral responsibility of the individual.

Royce tries to maintain that the doctrine of all-comprehensive Absolute influences his account of freedom: "Moral freedom is the freedom to hold by attention, or to forget by in attention, an Ought already present to one's finite consciousness" (McDermott, 1985, p. 175). For instance, even the idea of defeating evil in this world contributes to the well-being of individual and society. If one's self recognizes evil, it is also achieved by his attention that comes from his own will. This is the moral freedom that directly affects the self-realization of individuals in society. 
While, according to Royce, desire, choice and effort are certainly inseparable from will, J. Edwards holds the idea that freedom of choice and will-power are illusions. Since, in his determinism, he believes that we, as individuals, are not in the position to create our own ends. In his work Freedom of the Will, Edwards attacks the notion of a self-determining will. To him, the Arminians (a group of theologians who attempt to soften the harsh tenets of Orthodox Calvinism) consider the will as separate faculty, capable of determining its own volitions (acts of choosing) in the face of the strongest contrary motives. After dismissing "the self-determining will" as a logical absurdity, Edwards defines volition as merely "the realization in act of the soul's prevailing inclination and hence determined by the greatest apparent good" (1957, p. 142). "Good" means pleasing or agreeable. He maintains that man is free to do as he pleases, yet his choices occur in "casual series" and are foreseen and foreordained by God. "Man is not free to do otherwise than he pleases, yet he is still morally accountable; for it is the nature rather than the cause of volitions which renders them objects of moral judgment" (Benton, 1963, p. 261).

Furthermore, in the Freedom of the Will, Locke's statement that the will is perfectly distinguished from desire is rejected by Edwards who analyses this theory and then relates that a man's desire and will are virtually the same faculty of the soul. It can be assumed that the will at any moment is determined by the strongest motive acting upon the soul; we are free in so far as no obstacle is presented to our willing in accordance with our inclination, but our inclination is determined by what at any moment seems to us good. In his attack on the common arguments for the freedom of the will, Edwards is successful. If the notion by which the Arminians pursued to relieve God of the burden of evil in human life is disregarded, it is manifested as: Man's will is a faculty definitely indeterminate in itself and entirely independent of his inclinations. Therefore, a man errs because the choice between evil with its attendant suffering and good with its attendant happiness is presented to him. The man, having full knowledge of the results of his innate disposition, deliberately and freely chooses what is evil and painful.

Edwards, further, explains there must be an effect which must have a cause; if the will is determined, then there is a determiner. According to him, freedom of choice remains a real question since if our choices are caused, then freedom and responsibility are not real. He believes that the strongest motive causes us to choose as we do. If "good" is our choice, we regard it as good. We cannot choose what we regard as evil. From another sense, one alternative is that one's actions including one's acts of willing are preceded by an act of free will. On the second alternative, volitions are neither chosen by us nor determined by reasons, our character or by other states of the soul. But if they are not, then they aren't truly ours and we cannot be held responsible for them. 


\section{Determinism}

According to determinism, the acts of free human beings are not uncaused but self-caused. To say they are self-caused is not to say that they arise out of nothing or exist prior to themselves. Such would be an uncaused or self-caused being, which is nonsensical. However, self-determinism maintains that man's exercise of his freedom is self-caused, which is not contradictory. In other words, individuals exist and can freely cause their own actions (not their own being).

In Edwards' determinism, God reveals his Glory even in punishing sinners, and evil contributes to the grand design of God. Cause and effect hold throughout the universe, but the connection between them is a "constituted" one, continuing sovereign pleasure of God. This is also applied to the success of an individual's existence: though God's grace is independent of human means, it is experienced in the cause-effect realm as mankind devotes himself to the worship and service of God.

Describing freedom or liberty as being free from hindrance or impediment in the way of doing or conducting in any respect, Edwards defends the idea that every act is sustained by a series of God's acts: Every voluntary human act is caused. This means that each element in the casual chain is an occasion for God to choose another element to follow. In this sense, if I am determined to act in some way, it is because some desires are put into me before I realize, by the predestined Grace. Edwards, further, explains his philosophy through the terms "natural or moral inability." To him, inability signifies natural inability (things we are unable to do naturally, such as stupidity and paralysis) because a man cannot be truly said to be unable to do anything, when he can do it if he will. And moral inability denotes to what we are lacking to induce the act of our will. In other words, there are things that prevent us from doing what we desire, such as seven deadly sins in Christianity. Edwards is mistaken when he argues that human freedom is contrary to God's sovereignty. For God gives man free will; He sustains man so he can act freely, and He brings about all His purposes without violating man's free will. Thus, Edwards' position evidences a misunderstanding of free will.

As to Edwards' Christian concept of "God on the cross" and the sinful human nature, his pessimism is closely related to the Calvinistic approach, which sees God's power as arbitrary and the mankind as doomed to be damned. In this sense, his concept of God's sovereignty can be understood by his theory of "cause and effect" again. Edwards starts with the idea of occasionalism to explain causality, stating that our action creates not a result but a situation: the world is an ideal one; and the law of creating and the succession of these ideas are constant and regular. Edwards' occasionalism, and idealism provide a philosophical interpretation of God's absolute sovereignty. God is the only real cause and the only true substance. So, there is cause and effect relationship between God and man's act since human will won't be as strong as God's 
power. It is the glory of God who has a determination to order the world in a regular and discoverable way. From this respect, human nature needs God's help to reach salvation. It is God who creates the occasion in which human beings can find Him, who is giving salvation or a way to save the whole human community.

\section{The Individual in Emerson's Self-Reliance}

Emerson's point of view regarding the position of the individual in society needs to be scrutinized since Emerson begins his major work, Self-Reliance, on individualism by asserting the importance of thinking for oneself rather than meekly accepting other people's ideas. Emerson believes that all social evils are degradations of failures of the human spirit; therefore the solution to social problems lies in changing one's personal point of view. Emerson, who is socially conservative in his own way, dismisses any obligation the individual might have to others. In this sense, he rejects social action to help others for it weakens one's self-development. His famous quote in Self-Reliance says: "Do not tell me ... of my obligation to put all poor men in good situations. Are they my poor..?"(1989, p. 440). Therefore, in his social philosophy there is isolationism rather than the idea that the nature of personhood is necessarily social in individual's relationship to others. He sees social institutions and society of others as "perpetual disappointment," and "diminishment of the individual."

As a transcendentalist, Emerson develops a faith greater in individual moral sentiment than in revealed religion. He becomes undogmatic about Christianity. The quotes from his Self-Reliance are those that described best his philosophy: "to believe your own thought, to believe what is true for your private heart, is true for all men - that is genius.....Accept the place the divine providence has found for you; the society of your contemporaries, the connection of events ..."(1989, p. 438). What he means by self-reliance is free development and expression of the individual, who goes by his own judgments and follow his own lights, unfettered by either the demands of society or the options of others. For Emerson, the individual who is trying to be like others is prevented from performing his talents (caused by social communication).

In Self-Reliance, Emerson also emphasizes the idea that the individual should be completely reliant on God, and that every person has been put into their certain life and position by God and that the person needs to trust himself. He states that God has put the power to handle things, think, and act into each individual and that the individual needs to trust what God has put inside them to do things with their lives. Emerson's idea is that God has put the choice to us, but he has given us all of our unique gifts for the paths we can choose to take. He writes, "Trust thyself: every heart vibrates to that iron string..." (1989, p. 438). The meaningful metaphor of "iron string" connotes that the individual has the inner strength which might make him grasp the significance of his salvation as a freely bestowed gift by God. 
Emerson's faith is based on an intuitive belief in an ultimate unity, which he called the "over-soul." Each of us contains in microcosm the entirety of the over-soul. Therefore, every individual is to be respected because everyone has a portion of that over-soul (God). The human soul is part of this universal spirit to which it and other souls return at the moment of death. Emerson idealizes and purifies all aspects of our lives so that they reflect the full significance and value of the over-soul. (He attacked formal religion in an address he delivered at Harward Divinity School and defended intuitive spiritual experience.

Many philosophers like W. James, Oliver Wendel, Holmes, were to testify in behalf of "the liberation" they found in Emersonian self-reliance and individualism--to rid oneself from the materials of life and to follow new vocations that are better fitting one's needs. Others, like Dewey, appreciated the democratic element in his thought and faith in the power of ideas. Some others like H. James, saw in art a way to vindicate Emerson's faith in perception. In Emerson's concept, man isn't estranged from Nature, but intimate with her, sharing the "flow of her spiritual tides" and means of his creative powers of perceptions and ideas - "a creative self-sufficiency" of mankind - he goes through the way to reflect himself as creator of the future. Emerson believes in the power and freedom of a man to change things by himself and by the goodness of change itself. Through his radical philosophy based on an organic conception of the universe (on growth and development), Emerson celebrates, sanctifies and romanticizes the individual. For him, the person is the locus of freedom, power and accomplishment. In this way, individual is the most precious creation of the over-soul in the way that he needs to go through a process of purification - a kind of self-realization in order to become a part of the over-soul. In this sense, we can say that Emerson accepts a self-realization upon which our self-reliance is carried on.

\section{Conclusion}

Emerson's opinion of self-reliance is not only practiced individually, but also socially for the regeneration of society. Insisting on self-reliance as a virtue, Emerson also wants us to see his moral doctrine as the expression of the spirit of a young developing and promising society. In such a society, he envisions religion as an emotional communication between an individual soul and the universal "over-soul" of which it is a part. From this angle, being a part of the over-soul, in a way, reveals the way through which God expresses Himself in the world. Emerson also gives the idea of trusting ourselves through God. He relates that we have to trust in God to tell us what to do and what to think, which can also be considered as an experience of free will.

By contrast, Jonathan Edwards claims that will is not a faculty but the power of choice; in other words it is the choice itself. For good or ill, Edwards' influence on American life and letters extends far deeper and more extensively than we suppose. His legacy is quietly persistent, a gift or a harm to those who encounter it. Even though it sounds like a paradox: if I am powerless to affect 
my own salvation, I assert that the position of the free individual in such a society is not different from, but is a part of, the freedom of the Absolute. As Royce puts it, "the individual experience is identically a part of God's experience, not similar to a portion of God's experience, but identically the same as such portion" (Jarvis, 1975, p. 98).

On the other hand, J. Royce has the intention of finding a way to build a truly human community. For this reason, Royce creates a condition upon which the existence of a community depends on the fact that there are in the social world a number of distinct selves capable of social communications. Edwards' philosophy of community is based on the notion that communal life is essential since we can develop our love and show it in society. He emphasizes that selflove is required for the improvement of a society.

Consequently, in realizing his experience with free will in his society, the individual recognizes good and evil through a process of self-realization. As in Emersonian thought, the communication between the individual and God is achieved through self-reliance and self-recognition. "This entire world is present to the eternal divine consciousness as a single whole, and this whole is what the absolute chooses as his own expression" (Calkins, 1916, p. 289). Even though they express differences of opinions, J.Royce, J.Edwards and Emerson, have developed their own thought that becomes essential to understand the relationship between the individual and God. The position of the individual in society, in the philosophies of these thinkers, is reflected within the framework of the philosophy of community in which the individual can develop love and accomplishment by means of a communal life. Such an experience of the individual finally contributes to the fulfillment of the divine purpose - God's manifestation of Himself in the world.

\section{REFERENCES}

Benton, W. (Ed.). (1963). Encyclopedia Britannica Enc. Britannica: Inc.

Calkins M. W. (1916). The Foundation for Royce's Philosophy for Christian Theism. The Philosophical Review, 25(3), 282-296. Date of access: 12 Ocak 1999, http://links.jstor.org/sici.

Copleston, S. J. F. (1967). A History of Philosophy. Image Books.

Cury, D. (Ed.). (1986). Highlights of American Literature. English Language Programs Division. Washington: D. C.

Emerson, R. W. (1989). Self-Reliance. Nina Baym (Ed.) The Norton Anthology of American Literature, 437-454. W.W.W. Norton and Company.

Edwards, J. (1957). Freedom of the Will. Paul Ramsey(Ed.). (p. 41). New Haven: Yale Un. Press.

(1960). The Nature of True Virtue. William K. Frankena (Ed.) Ann Arbor: Un. Of Michigan Press. 
Haldar, H. (1899). The Conception of the Absolute. The Philosophical Review, 8 (261), p.72.

Jarvis E. A. and Frank A. O. (1975). The Conception of God in the Later Royce. Kluwer Academic Publishers.

Mc Dermott, J. (1985). Josiah Royce's Philosophy of the Community: Danger of the Detached Individual. American Philosophy, 153-176. Cambridge University Press.

Singer, M. (Ed.). (1985). American Philosophy. Cambridge University Press.

Royce, J. (1885).The Religious Aspect of Philosophy. Boston: Houghton Mifflin.

(1898). Studies of Good and Evil. New York: D. Appleton.

Stephen R. Y. and John C. A. (Ed.). (1993). The Edwardsean Legacy. Delightful Conviction: Jonathan Edwards and the Rhetoric of Conversion. Greenwood Press.

\section{CONCEPTS OF SELF-REALIZATION, FREEDOM, FREE WILL AND DETERMINISM IN AMERICAN PHILOSOPHY}

Abstract: American philosophy takes its subject from many different areas one of which is the religious aspect that scrutinizes the position of the individual on earth as well as his relationship with God. The idea that human nature needs God to reach salvation is closely related to the moral freedom of the individual and therefore to his contribution to the community he belongs to. To better grasp the existence of God who expresses Himself in the world, the individual, as the most intelligent and precious thing in the creation, needs to go through a process that leads him achieve self-realization and accomplishment. This paper aims at demonstrating the position of the individual in his community in relation to his recognition of God. Although they possess differences of opinions, the three prominent American thinkers, chosen to be discussed have an important place in the 19th century American thought. J.Royce, J.Edwards and R.W. Emerson, have developed their own ways of thinking that are essential to discuss regarding the relationship between the individual and God. To explore this notion I need to scrutinize the concepts of self-realization, freedom and free will, and determinism which will finally shed light to the idea that God expresses Himself through the experience of individual in his society. Furthermore, examining these concepts through a comparative approach is important to make a distinction among the thinkers' ways of thinking. Thus, in realizing his experience, the individual recognizes good and evil that will also lead the improvement of society he lives in.

Keywords: Self-realization, Free Will, Determinism, J.Royce, J.Edwards, R.W.Emerson. 